\title{
Policy Instruments to Promote Electro-Mobility in the EU28: A Comprehensive Review
}

\author{
José M. Cansino ${ }^{1,2, *(1)}$, Antonio Sánchez-Braza ${ }^{1}$ [i] and Teresa Sanz-Díaz ${ }^{1}$ \\ 1 Departamento de Análisis Económico y Economía Política, Universidad de Sevilla, 41018 Sevilla, Spain; \\ asb@us.es (A.S.-B.); mtsanz@us.es (T.S.-D.) \\ 2 Universidad Autónoma de Chile, Av. Pedro de Valdivia 425, Providencia, Región Metropolitana 7500912, \\ Chile \\ * Correspondence: jmcansino@us.es
}

Received: 8 June 2018; Accepted: 16 July 2018; Published: 18 July 2018

\begin{abstract}
Despite its environmental benefits, the amount of Electric Vehicles (EVs) in use within the European Union 28 is still very limited. Poor penetration might be explained by certain factors that dissuade potential buyers. To balance these factors and promote electro-mobility, Member States have established incentives to increase demand. However, the various measures are scattered. This paper contributes to fill the gap in the literature by offering an overall view of the main measures. The authors will focus on measures to promote electro-mobility within the EU28 until 2014. After an in-depth and comprehensive review of the relevant measures, the authors conclude that the most important policy instruments to promote EVs are tax and infrastructure measures in addition to financial incentives for purchasing and supporting R\&D projects. Regardless of the scarcity of EV registration data, the available information allows us to conclude that higher EV penetration levels appear in countries where the registration tax, the ownership tax, or both taxes have developed a partial green tax by including $\mathrm{CO}_{2}$ emissions in the calculation of the final invoice.
\end{abstract}

Keywords: electric vehicle; electro-mobility promotion; policy instruments; tax and infrastructure measures; financial incentives; supporting R\&D projects

\section{Introduction}

In the European Alternative Fuels Strategy, it is believed that an appropriate combination of fuels will be able to break the dependence on oil and improve energy supply security [1]. Furthermore, the European Union (EU) also considers that the development of alternative fuels would improve economic growth, strengthen industry competitiveness, and promote employment [2]. Lastly, alternative fuels reduce greenhouse gas (GHG) emissions from transportation, which allows the targets set in the H2020 strategy to be attained.

The H2020 strategy is the most ambitious EU package to date and it seeks to fight against global warning. It includes a specific $20 \%$ target for increasing the share of the renewable energy source (RES), which is up to $20 \%$ for the final energy, and reducing GHG emissions up to $20 \%$ from the 1990 levels [3]. The European Council [4] extended this objective to $40 \%$ by 2030 . Without setting an obligatory objective, the White Paper on Transport also establishes the aim of reducing $60 \% \mathrm{CO}_{2}$ emissions in transportation by 2050 [5].

As one of the main alternative energy sources for transportation, the electric motor could be used mainly on the highway, in cities, and rail transportation for travelers and for delivering goods. Electric vehicles (EVs) could reduce GHG emissions and improve city air quality and, therefore, the health of their populations because they only emit natural by-products rather than exhaust fumes [6-8]. Yet, from the potential buyer perspective, this environmental benefit may be less important because society, 
by nature, is individual and hedonic [9]. There is critical research on this environmental benefit. In this sense, Perujo and Ciuffo [10] observe that EVs can really represent a realistic alternative both in terms of the electric grid available capacity and $\mathrm{CO}_{2}$ emissions reduction. It could heavily impact the daily requested electric power. Moreover, Camus et al. [11] study different scenarios for EVs penetration and charging profiles and concluded for a strong EVs penetration scenario that local emissions (CO, $\mathrm{NO}_{x}, \mathrm{HC}$, and $\mathrm{PM}$ ) decreased to $10 \%$ by the replacement of light duty Internal Combustion Engine Vehicles by EVs, but were replaced by $8 \%$ local emissions increase from electricity generation $\left(\mathrm{NO}_{\mathrm{x}}\right.$, $\mathrm{SO}_{2}$ ) when providing the extra energy for EVs recharging.

Despite the environmental benefits, the number of EVs in use is still very limited. In 2013, there were 123,188 EVs registered, which represents $1.1 \%$ of the total number of vehicles registered that year in EU28, which was a total of 10,801,973 vehicles [12]. The limited share of EVs is also present in the US [13] as well as in China and Japan [14].

Poor penetration might be explained by a number of different factors that dissuade potential buyers, which was reviewed by Coffman et al. [15] and the study by Sierzchula et al. [16]. Coffman et al. [15] group these factors into internal, external, and applied policies. In the first group, there is a higher initial investment [17-19], an extended recharging time, and a limited range [20]. Second, Coffman et al. [15] include relative fuel prices [16] and the characteristics of potential consumers, but the literature is inconclusive. The availability of charging stations is also important, which Sierzchula et al. [16] note as one of the most influential factors in the decision to purchase an EV, and public visibility/social norms. In the latter group, Coffman et al. [15] includes financial and non-financial incentives, public support for the construction of recharging infrastructure, and awareness-raising.

To balance these factors and promote electro-mobility, Member States (MSs) have established incentives to increase the demand. Like other, low carbon energy strategies, market penetration speed could be increased by public policies [21-23].

Often, the various measures appear scattered and they are not shown as a whole. As a consequence, research is needed but not only oriented to review measures in. It is also needed for analyzing national incentive frameworks to group measures in homogeneous sets and allow for the comparison between countries. In this paper, the research process implied feed-back between national authorities and coauthors before addressing measures in the right set. The aim of this paper is to fill the gap in the literature by offering an overall view of the main measures. This study will focus on measures up to 2014 to promote electro-mobility by using Plug-in EVs in the EU28. The end of the period under analysis coincides with Directive 2014/94/UE on alternative fuel deployment. Due to the lack of data on registered cars in EU after 2012, Directive 2014/94/UE constitutes a relevant milestone for further analysis when data is available. The Plug-in EV category includes the following list: Pure EVs or Battery EVs (BEVs), Extended-Range EVs (EREVs), and Plug-In Hybrid EVs (PHEVs). Hannan et al. [6] offer a recent and useful review of these alternative vehicles. In general, we refer to them as EVs. Nonetheless, many of the promotional measures presented in this paper also apply to other low carbon-emissions vehicles.

This paper is organized as follows. After this introduction, Section 2 analyzes the public policies applied to promote the acquisition of EVs such as taxes, measures to develop the recharge point infrastructure, the main financial incentives, the measures supporting $R \& D$ projects, and the actions aimed at improving consumer perception. In Section 3, the major findings in light of the relevant data available are discussed before drawing conclusions in Section 4.

\section{Public Policies Applied to Promote the Acquisition of EVs}

After an in-depth and comprehensive review of the relevant measures, the most important ones include tax measures, those oriented toward infrastructure, financial incentives for the purchase support of Research and Development (R\&D) projects, and projects enhancing consumer perception. 
All of them focus on correcting external and internal factors, which is pointed out by Coffman et al. [15]. Therefore, they fall within the third group of factors mentioned above: the policies applied, which are classified according to Table 1.

Table 1. Classification of measures analyzed in the EU.

\begin{tabular}{|c|c|c|}
\hline \multicolumn{2}{|c|}{ Applied Public Policies [15] } & Measures Implemented in the EU \\
\hline \multirow[t]{2}{*}{ Incentives } & Financial & $\begin{array}{c}\text { Tax } \\
\text { Aids/subsidies }\end{array}$ \\
\hline & Non-financial & Other benefits to EVs owner \\
\hline \multicolumn{2}{|c|}{ Public support for recharging infrastructure } & Public or subsidized recharge points \\
\hline \multicolumn{2}{|c|}{ Sensitization of the population } & $\begin{array}{l}\text { Awareness Campaigns } \\
\text { Support for R\&D }\end{array}$ \\
\hline
\end{tabular}

Source: Based on the classification of Coffman et al. [15].

\subsection{Financial Incentives: Tax Measures}

Based on the amount collected, the most important taxes in the EU are the value-added tax (VAT), registration fees, and the vehicle ownership tax. The first of these is not significant in this paper because no Member State (MS) has established a reduced VAT when purchasing EVs. Therefore, common rates are applied and the tax rates range from $15 \%$ in Luxembourg to $27 \%$ in Hungary. This section focuses on registration fees and ownership taxes. Some measures include personal income tax and corporate tax, which are also referred to in this paper.

\subsubsection{Registration Fees}

Registration fees work as a special tax on motor vehicles applied to the first and initial registration. It includes two types of taxes, which are the registration tax and the license tax. Both are paid when the vehicle is first registered although they involve a variety of concepts.

License fees are administrative fees. The purpose of these fees is to offset the administrative costs of the registration process. It is a fixed amount, which normally does not depend on technical or environmental parameters. However, in the cases of Cyprus and France, reductions do exist.

Cyprus applies a $15 \%$ discount for those which emit less than $150 \mathrm{~g}$ of $\mathrm{CO}_{2}$ per $\mathrm{Km}$ [24-26]. In France, individual regions are allowed to establish a total or 50\% exemption of the EV license fee.

Yet, the registration tax seeks to levy the purchasing power shown in the acquisition. The amount depends on the vehicle's value and technical specifications. Table 2 provides detailed information about the parameters that influence the amount of the registration fee in each MS.

Table 2. Determinants of registrations taxes in each MS of EU28.

\begin{tabular}{ccccc}
\hline Countries & No Registration Tax & Emissions & Environmental Standards & Others \\
\hline Austria & & $\bullet$ & & $\diamond$ \\
Belgium & $\bullet$ & & & $\bullet$ \\
Bulgaria & $\bullet$ & $\bullet$ & & \\
Croatia & $\bullet$ & $\bullet$ & $\bullet$ & $\bullet$ \\
\hline $\begin{array}{c}\text { Cyprus } \\
\text { Czech Republic } \\
\text { Denmark }\end{array}$ & $\bullet$ & & & $\bullet$ \\
Estonia & $\bullet$ & $\bullet$ & & \\
\hline Finland & & $\bullet$ & & \\
France & & & & \\
Germany & & & & \\
Greece & & & & \\
\hline
\end{tabular}


Table 2. Cont.

\begin{tabular}{|c|c|c|c|c|}
\hline Countries & No Registration Tax & Emissions & Environmental Standards & Others \\
\hline Hungary & & & $\bullet$ & $\bullet$ \\
\hline Ireland & & $\bullet$ & & \\
\hline Italy & & & & $\diamond$ \\
\hline Latvia & & $\bullet$ & & \\
\hline Lithuania & - & & & \\
\hline Luxembourg & $\bullet$ & & & \\
\hline Malta & & $\bullet$ & & $\bullet$ \\
\hline Netherlands & & $\bullet$ & & $\bullet$ \\
\hline Poland & & & & $\diamond$ \\
\hline Portugal & & $\bullet$ & & $\bullet$ \\
\hline Romania & & $\bullet$ & $\bullet$ & $\bullet$ \\
\hline Slovak Republic & & & & $\diamond$ \\
\hline Slovenia & & $\bullet$ & & $\bullet$ \\
\hline Spain & & $\bullet$ & & \\
\hline Sweden & $\bullet$ & & & \\
\hline United Kingdom & $\bullet$ & & & \\
\hline
\end{tabular}

Source: [26]. Note: Diamonds in the last column indicate that this tax do not consider any environmental characteristics. Black dots in the same column indicate the tax included in the environmental parameters.

Table 2 shows that eight MSs do not apply a registration tax. These countries include $35.1 \%$ of the EU population. Four of the countries (the diamonds in Table 2) that have established this tax do not consider any environmental characteristics. The other sixteen countries use certain environmental parameters.

Seven out of the 20 MSs that have established registration taxes include a tax credit for the registration of EVs. The detail is shown in the third column of Table 3. In those MSs, EVs enjoy full exemption. 
Table 3. Tax credit in tax measures of EVs.

\begin{tabular}{|c|c|c|c|c|}
\hline \multirow{2}{*}{ Countries } & \multirow{2}{*}{ Registration Fee } & \multirow{2}{*}{ Registration Tax } & \multicolumn{2}{|c|}{ Vehicle Ownership Tax } \\
\hline & & & Private & Commercial \\
\hline Austria & & $\begin{array}{l}\text { BEVs are exempt. Hybrids have } \\
\text { an allowance of } € 600\end{array}$ & EVs are totally exempt & \\
\hline Belgium & & $\begin{array}{l}\text { Individual regions may } \\
\text { establish environmental bonus } \\
\text { and penalties }\end{array}$ & EVs pay a minimum amount & \\
\hline Bulgaria & & & Based on the horsepower and vehicle age [24] & $\begin{array}{l}\text { There is a time-based vignette system in } \\
\text { place for passenger cars and heavy-duty } \\
\text { vehicles }[27,28]\end{array}$ \\
\hline Croatia & & No tax credit & Based on vehicle age & \\
\hline Cyprus & $\begin{array}{l}15 \% \text { discount for those } \\
\text { who emit less than } 150 \mathrm{~g} \\
\text { of } \mathrm{CO}_{2} / \mathrm{Km}\end{array}$ & $\begin{array}{l}\text { Exempt for those who emit less } \\
\text { than } 120 \mathrm{~g} \text { of } \mathrm{CO}_{2} / \mathrm{Km}\end{array}$ & EVs do not pay & \\
\hline Czech Republic & & & & $\begin{array}{l}\text { Only applied to commercial vehicles and } \\
\text { BEVs and hybrids are exempt }\end{array}$ \\
\hline Denmark & & $\begin{array}{l}\text { BEVs had a limited exemption } \\
\text { from } 2010 \text { [29] until } 2015\end{array}$ & Tax according to fuel consumption & Tax according to fuel consumption \\
\hline Finland & & BEVs pay the minimum & $\begin{array}{l}\text { Amount varies between } € 20 \text { and } € 605 \text {, } \\
\text { according grams of } \mathrm{CO}_{2}[30]\end{array}$ & \\
\hline France & $\begin{array}{l}\text { Individual regions are } \\
\text { allowed to establish a total } \\
\text { or } 50 \% \text { exemption }\end{array}$ & $\begin{array}{l}\text { Exempt those who emit less } 130 \\
\qquad \mathrm{~g} \text { of } \mathrm{CO}_{2} / \mathrm{Km}\end{array}$ & $\begin{array}{l}\text { Vehicles that emit more than a } 190 \mathrm{~g} / \mathrm{km} \text { pay } \\
\qquad 160 \text { fee }\end{array}$ & $\begin{array}{l}\text { BEVs are exempt, but hybrids enjoy an } \\
\text { exemption for } 2 \text { years if they emit less } \\
\text { than } 110 \mathrm{~g} / \mathrm{km} \text { (for passengers vehicles) }\end{array}$ \\
\hline Germany & & & EVs are exempts for ten years & $\begin{array}{l}\text { After } 10 \text { years of total exemption, there is } \\
\text { a 50\% reduction (for passengers vehicles) }\end{array}$ \\
\hline Greece & & Commercial EVs are exempt & $\begin{array}{l}\text { Vehicles emitting less than } 100 \mathrm{~g} / \mathrm{km} \text { are } \\
\text { exempts }\end{array}$ & \\
\hline Hungary & & $\begin{array}{l}\text { BEVs are exempt. Hybrids pay } \\
\text { only } € 247\end{array}$ & $\begin{array}{l}\text { Based on vehicle age, EVs are completely } \\
\text { exempt }\end{array}$ & \\
\hline Ireland & & $\begin{array}{c}\text { BEVs are exempts. A limit of up } \\
\text { to } € 2500 \text { rebate for PHEVs } \\
{[26,31]}\end{array}$ & $\begin{array}{l}\text { Zero emissions vehicles only pay } € 120 \text { each } \\
\text { year, } € 50 \text { less than the next stretch }\end{array}$ & \\
\hline
\end{tabular}


Table 3. Cont.

\begin{tabular}{|c|c|c|c|c|}
\hline \multirow{2}{*}{ Countries } & \multirow{2}{*}{ Registration Fee } & \multirow{2}{*}{ Registration Tax } & \multicolumn{2}{|c|}{ Vehicle Ownership Tax } \\
\hline & & & Private & Commercial \\
\hline Italy & & $\begin{array}{l}\text { Individual regions may } \\
\text { establish environmental bonus } \\
\text { and penalties }\end{array}$ & $\begin{array}{l}\text { EVs are exempt for the first five registration } \\
\text { years and an exemption of } 75 \% \text { is given } \\
\text { afterwards (According to regions) }\end{array}$ & $\begin{array}{l}\text { EVs: there are no ownership tax for the } \\
\text { first five registration years of a vehicle } \\
\text { and an exemption of } 75 \% \text { is given } \\
\text { afterwards (according to regions) }\end{array}$ \\
\hline Latvia & & BEVs are exempt & Based on vehicle age & \\
\hline Malta & & No tax credit & Based on vehicle age & \\
\hline Netherlands & & $\begin{array}{l}\text { Exempt those who emit less } 88 \\
\text { for petrol and } 85 \text { for diesel } g \text { of } \\
\qquad \mathrm{CO}_{2} / \mathrm{Km}\end{array}$ & $\begin{array}{l}\text { Vehicles emitting less than } 50 \mathrm{~g} / \mathrm{km} \text { are } \\
\text { exempts (until 2015) }\end{array}$ & \\
\hline Poland & & No tax credit & & \\
\hline Portugal & & No tax credit & Based on vehicle age and emissions & \\
\hline Romania & & All EVs are tax exempt & & \\
\hline Slovak Republic & & No tax credit & & \\
\hline Slovenia & & No tax credit & & \\
\hline Spain & & $\begin{array}{l}\text { Exempt among those who emit } \\
\text { less } 120 \mathrm{~g} \text { of } \mathrm{CO}_{2} / \mathrm{Km}\end{array}$ & $\begin{array}{l}\text { Town halls have the authority to establish } \\
\text { environmental deductions up to } 75 \%\end{array}$ & \\
\hline Sweden & & & $\begin{array}{l}\text { Hybrids and BEVs are exempts for five years if } \\
\mathrm{CO}_{2} \text {-emissions and energy consumption are } \\
\text { under } 120 \mathrm{~g} / \mathrm{km} \text { and } 37 \mathrm{kw} / \mathrm{h} \text { per } 100 \mathrm{~km}\end{array}$ & $\begin{array}{l}\text { EVs up to } 3500 \mathrm{Kgs} \text { are exempt for } 5 \\
\text { years; hybrid buses pay only } € 115\end{array}$ \\
\hline United Kingdom & & & $\begin{array}{l}\text { Vehicles emitting less than } 100 \mathrm{~g} / \mathrm{km} \text { are } \\
\text { exempts }\end{array}$ & \\
\hline
\end{tabular}


In Cyprus, France, the Netherlands and Spain, EVs pay no registration tax. These MSs account for $25 \%$ of the EU28 population and almost $40 \%$ of the 20 MSs' population that levy this tax.

In Belgium, registration taxes are defined by each region while the federal government also establishes measures that favor environmentally-friendly vehicles through the same tax [32]. Flanders and Wallonia use the registration tax to reduce vehicle $\mathrm{CO}_{2}$-emissions (these two regions account for almost $90 \%$ of the Belgian population [33]). In March 2012, the Flemish Authorities modified the registration tax applied to green cars. The current tax is based on the type of fuel used, the level of $\mathrm{CO}_{2}$ emissions, the Euro norm, and age. Cars that emit less than $81 \mathrm{~g} \mathrm{CO}_{2} / \mathrm{km}$ receive a premium of $€ 500$ to $€ 3500$. For cars emitting more than $146 \mathrm{~g} \mathrm{CO}_{2} / \mathrm{km}$, an Ecomalus of up to $€ 2500$ applies. Yet, in the Brussels-Capital region, the registration tax is only based on horsepower and age [34]. Financial assistance with a maximum of $€ 5000$ has, nevertheless, been established for commercial vehicles.

In the case of Italy, provinces may establish a maximum surcharge of $30 \%$ for registration tax. Therefore, almost all of the provinces have established that maximum and only six have levied a lower surcharge for EVs, which accounts for little more than $4 \%$ of the country's population [33].

\subsubsection{Vehicle Ownership Tax}

The vehicle ownership tax is a local tax. This tax levies the ownership of mechanically-driven vehicles suitable for driving on public roads. It must be paid periodically by the vehicle owner. The amount depends on technical parameters and other aspects such as environmental impact, consumption, or business use. Table 4 shows the parameters considered, respectively, when taxing vehicle ownership for private and commercial purposes in the EU28.

In the Czech Republic, Estonia, Lithuania, and Poland, private vehicles are not levied by this tax. Eleven out of the remaining MSs only consider technical parameters. Therefore, only 13 MSs include some type of environmental parameter.

Age is used in Bulgaria, Croatia, Hungary, Italy, Latvia, and Malta. Paradoxically, despite older vehicles possibly having a greater environmental impact, only in Malta does the levy increase accordingly as the vehicle ages. Consequently, this discourages fleet renewal.

As far as we know, 25 MSs have established taxes for commercial vehicles. These countries include almost $99 \%$ of the EU28 population. Furthermore, these taxes depend mainly on technical characteristics such as weight, the number of axles, and the type of suspension. Only six countries include some type of environmental parameter (see Table 4). 
Table 4. Determinants of taxes on vehicle's ownership in each MS of EU28.

\begin{tabular}{|c|c|c|c|c|c|c|c|c|}
\hline \multirow{2}{*}{ Countries } & \multicolumn{2}{|c|}{ No Registration Tax } & \multicolumn{2}{|c|}{ Emissions } & \multicolumn{2}{|c|}{ Environmental Standards } & \multicolumn{2}{|c|}{ Others } \\
\hline & Private & Commercial & Private & Commercial & Private & Commercial & Private & Commercial \\
\hline Austria & & & & & & & $\diamond$ & $\diamond$ \\
\hline Belgium & & & & & & & $\diamond$ & $\diamond$ \\
\hline Bulgaria & & & & & & $\bullet$ & $\diamond$ & $\bullet$ \\
\hline Croatia & & & & & & & $\diamond$ & \\
\hline Cyprus & & & $\bullet$ & & & & & \\
\hline Czech Republic & $\bullet$ & & & & & & & $\diamond$ \\
\hline Denmark & & & & & $\bullet$ & $\bullet$ & & $\bullet$ \\
\hline Estonia & $\bullet$ & & & & & & & $\diamond$ \\
\hline Finland & & & $\bullet$ & & & & - & $\diamond$ \\
\hline France & & & $\bullet$ & $\bullet$ & & & & $\bullet$ \\
\hline Germany & & & - & & & - & & - \\
\hline Greece & & & $\bullet$ & & & & $\bullet$ & $\diamond$ \\
\hline Hungary & & & & & & & $\diamond$ & $\diamond$ \\
\hline Ireland & & & $\bullet$ & & & & & $\diamond$ \\
\hline Italy & & & & & - & & & $\diamond$ \\
\hline Latvia & & & & & & & $\diamond$ & $\diamond$ \\
\hline Lithuania & $\bullet$ & & & & & & & $\diamond$ \\
\hline Luxembourg & & & $\bullet$ & & & & & $\diamond$ \\
\hline Malta & & & & & & & $\diamond$ & \\
\hline Netherlands & & & $\bullet$ & & & & $\bullet$ & $\diamond$ \\
\hline Poland & $\bullet$ & & & & & & & $\diamond$ \\
\hline Portugal & & & - & & & & - & $\diamond$ \\
\hline Romania & & & & & & & $\diamond$ & $\diamond$ \\
\hline Slovak Republic & & & & & & & $\diamond$ & $\diamond$ \\
\hline Slovenia & & & & & & & $\diamond$ & $\diamond$ \\
\hline Spain & & & & & & & $\diamond$ & $\diamond$ \\
\hline Sweden & & & - & & - & - & - & - \\
\hline United & & & & & & & & \\
\hline Kingdom & & & $\bullet$ & & & $\bullet$ & & 0 \\
\hline
\end{tabular}

Source: [26]. Note: Diamonds in the last column indicate that this tax does not consider any environmental characteristics and black dots in the same column indicate the tax included environmental parameters. 


\subsubsection{Measures Included in Income Tax and in Corporate Tax}

In addition to the measures included in the registration tax and the tax on vehicle ownership, there are other measures affecting other taxes. The most relevant taxes to be considered are the income tax and the corporate tax.

Two types of incentives are included in the income tax. The first incentive, in the case of an employee receiving a company car, is that its value (total or partial) must be incorporated into the taxable base as a part of income. Second (Incentive 2 in Table 5), the purchase of an EV may produce a deduction in the tax. This is the case in Portugal, Belgium, the UK, the Netherlands, Sweden, and Germany.

With regard to Incentive 1, it is also necessary to consider that the private use of a corporate vehicle involves an income that depends on the value of the vehicle. Four countries have total (UK) or partial (the Netherlands, Sweden, and Germany) exemptions.

Some countries also have established tax measures for the corporate tax. Belgium and Portugal are two examples (see the last column of Table 5).

Table 5. Tax credit in tax measures of EVs (II).

\begin{tabular}{|c|c|c|c|}
\hline \multirow{2}{*}{ Countries } & \multicolumn{2}{|c|}{ Income Tax } & \multirow{2}{*}{ Corporate Tax } \\
\hline & Incentive 1 & Incentive 2 & \\
\hline Belgium & $\begin{array}{l}\text { Until 2015, this income was } \\
\text { exempt for EVS. }\end{array}$ & $\begin{array}{l}\text { Reduction of } 15 \% \text { up to } € 4940 \text {. } \\
\text { Brussels Regions has established a } \\
\text { subsidy of up to } € 5000 \text { for the } \\
\text { acquisition of BEVs and hybrids } \\
\text { commercial. } \\
\text { BEVs only are subjected to the } \\
\text { minimum tax solidarity contribution, } \\
\text { an extra fee that must be paid for } \\
\text { commercial vehicles utilized for } \\
\text { private use [32]. }\end{array}$ & $\begin{array}{l}\text { Subsidizes the } 20 \% \text { of the } \\
\text { extra cost involving the } \\
\text { purchase of EVs and } \\
\text { charging point } \\
\text { installation up to } \\
€ 14,375 \text {. }\end{array}$ \\
\hline Germany & $\begin{array}{l}\text { Have an adjustment method to } \\
\text { offset the higher value of EVs. }\end{array}$ & & \\
\hline Netherlands & $\begin{array}{l}\text { Reduction percentage depends } \\
\text { on emissions. EVs pay } 4 \% \\
\text { instead of } 25 \% \text {. }\end{array}$ & & \\
\hline Portugal & & $\begin{array}{l}\text { Decreasing of } 30 \% \text {, with a limit of up } \\
\text { to } € 796 \text {. There is an additional } \\
\text { incentive of } € 5000 \text { for a scrapped car. }\end{array}$ & $\begin{array}{l}\text { There is a deduction of } \\
50 \% \text { of the purchasing } \\
\text { price in corporate tax if } \\
\text { an old vehicle is } \\
\text { scrapped. }\end{array}$ \\
\hline Sweden & Reduced by $40 \%$. & & \\
\hline
\end{tabular}

\subsection{Financial Incentives: Aids and Other Measures}

The use of financial incentives is less extended than previous political instruments but it is the most visible type of incentive for the EV purchase credit. Twelve MSs carried out remarkable initiatives, which is presented in Table 6. Most of these countries have opted for direct aid, which is shown in column 1 . Nevertheless, some have combined this with other measures such as those detailed in the third column of Table 6. 
Table 6. Financial Incentives applied in some countries of EU: direct aids and others measures.

\begin{tabular}{|c|c|c|}
\hline Countries & Direct Aids & Other Measures \\
\hline Austria & $\begin{array}{l}\text { 1. 2007-2013: 10,000 EVs were funded with } € 10.8 \text { Mio., among them: } 7778 \\
\text { E-Bikes, } 566 \text { E-Scooter/Motorcycles, } 1118 \text { E-Cars and light duty vehicles. } \\
\text { 2. New funding flat rates for EVs are: E-Bikes, } € 400 \text {, E-Scooter } € 500 \text {, E-Car } \\
€ 4000 \text {. }\end{array}$ & $\begin{array}{l}\text { The 'klima:aktiv program' [35,36]: It included the traffic climate action } \\
\text { program for climate-friendly mobility that proffers integral aid in this field } \\
\text { to private companies, local associations, and communities. }\end{array}$ \\
\hline Belgium & & $\begin{array}{l}15 \% \text { assessment of the environmental criteria on the score of the contract } \\
\text { adjudications. The goal that } 50 \% \text { of all public acquisition processes } \\
\text { correspond to sustainable procurements. In accordance with that, the } \\
\text { public contract adjudications have to be made based on an ecological score } \\
\text { system. A minimum eco-score for cars of } 70 / 100 \text { was established as } \\
\text { desirable share for the procurement of vehicles of public institutions from } \\
2010 \text { with the additional consideration that public vehicles having an } \\
\text { eco-score value below } 50 \text { should be avoided. }\end{array}$ \\
\hline Bulgaria & $\begin{array}{l}\text { 1. There is a program with a global budget about } € 1.3 \text { billion whose preference } \\
\text { is to reach the goal of incrementing the number of eco-friendly vehicles. } \\
\text { 2. Project that finances the development of programs promoting the use of } \\
\text { renewable energy including procurement programs for EVs. These programs } \\
\text { can be financed with grants and loans up to } 20 \% \text { [37]. }\end{array}$ & \\
\hline Cyprus & $\begin{array}{l}\text { 1. } € 22,566 \text { as premium for the purchase of an EV. The limits were a maximum } \\
\text { bonus of } € 700 \text { for the purchase of new EVs not exceeding the limit of } 120 \mathrm{~g} / \mathrm{km} \\
\mathrm{CO}_{2} \text { emissions and bonus of } € 1200 \text { at max for the procurement of a hybrid EV. } \\
\text { 2. There is a program of incentives for withdrawing an old vehicle from } \\
\text { circulation. Subsidies vary from } € 257 \text { to } € 1800 \text { [38]. }\end{array}$ & \\
\hline France & $\begin{array}{l}\text { Purchasers obtain an incentive of } € 5000 \text { when acquiring a car that does not } \\
\text { exceed } 60 \mathrm{~g} / \mathrm{km} \mathrm{CO}_{2} \text { emissions. }\end{array}$ & $\begin{array}{l}\text { In 2011, the Environmental Ministry of France arranged the distribution of } \\
50,000 \text { EVs to about } 20 \text { public and private companies. }\end{array}$ \\
\hline Ireland & These actions provide investment support for the first $6000 \mathrm{EVs}$ sold. & $\begin{array}{l}\text { To implement these measures, the aid is supplied to selected EVs dealer, } \\
\text { which are responsible for providing the discounts to the final purchasers } \\
\text { of EVs. }\end{array}$ \\
\hline Italy & $\begin{array}{l}\text { Vehicles emitting less than } 50 \mathrm{~g} / \mathrm{km} \text { including BEVs and hybrids receive a } \\
\text { subsidy of } 20 \% \text { after tax (limit of } € 5000 \text { ). }\end{array}$ & \\
\hline Luxembourg & $\begin{array}{l}\text { BEVs and PHEVs, which emits less than } 60 \mathrm{~g} / \mathrm{km} \text {, may receive a } € 5000 \text { subsidy } \\
\text { in the procurement if the purchaser contracts a green electricity supply. }\end{array}$ & \\
\hline
\end{tabular}


Table 6. Cont

\begin{tabular}{|c|c|c|}
\hline Countries & Direct Aids & Other Measures \\
\hline Portugal & $\begin{array}{l}\text { 1. } 2008 \text { and 2010: purchasers received a grant of } € 1000 \text { if they substituted a } \\
10-15 \text { years old vehicle for a new one that does not exceed the limit of } 130 \mathrm{~g} / \mathrm{km} \\
\mathrm{CO}_{2} \text { emissions. This incentive amounts to the } € 1250 \text { if the vehicle age was more } \\
\text { than } 15 \text { years. } \\
\text { 2. From 2010, this grant was diminished to } € 750 \text { or } € 1000 \text {, respectively. }\end{array}$ & \\
\hline Slovak Republic & $\begin{array}{l}\text { Public transportation benefited from this measures because it included the } \\
\text { purchase of new transportation equipment/vehicles for it. The funding volume } \\
\text { covers } 85 \% \text { of the investment maximum (FREE Governmental Program for } \\
\text { Competitiveness and Economic Growth (2007-2013)). }\end{array}$ & \\
\hline Spain & $\begin{array}{l}\text { 1. Local authorities offer investment support with incentives from } € 2000 \text { to } \\
€ 7000 \text { for purchasing EVs and other low } \mathrm{CO}_{2} \text { emissions cars. } \\
\text { 2. For municipalities with } 50,000 \text { or more inhabitants ( } 145 \text { cities) a } 20 \% \text { subsidy } \\
\text { is applied for the purchase of EVs ( } € 6000 \text { max/unit). } \\
\text { 3. Incompatible with the specific grants for EVs included in the plan MOVELE } \\
\text { depending on the region of Spain. The amount could surpass } € 5500 \text {. }\end{array}$ & $\begin{array}{l}\text { Since 2012, the government of Spain launched the PIVE Plan, which had } \\
\text { the objective to renew private and light commercial vehicles. With an } \\
\text { allocation of } € 1120 \text { Mio, 1,185,000 vehicles were removed from circulation } \\
\text { and substituted for others, which, for the most part, emit less than } \\
120 \mathrm{~g} / \mathrm{km} \text {. }\end{array}$ \\
\hline Sweden & $\begin{array}{l}\text { 1. Investment aid in } 25 \% \text { over extra cost, with maximum levels of } € 10,259.11 € \\
\text { and } € 5129.55 € \text { for the first } 75 \text { EVs and the next } 1000 \text { EVs sold, respectively. } \\
2 \text {. An extra-bonus for low emission vehicles may be also applied since early } \\
2012 \text { with investment aid for an amount of up to } € 4103.60 \text { [39-41]. }\end{array}$ & $\begin{array}{l}\text { The taxable appraisal of the EVs is diminished by } 40 \% \text { when compared } \\
\text { with similar fossil fuel cars, with a limit on this diminution of } \\
€ 1639.15 \text { per year. }\end{array}$ \\
\hline United Kingdom & $\begin{array}{l}\text { Since 2011, the purchase of a BEV or PHEV emitting less than } 75 \mathrm{~g} \mathrm{CO}_{2} / \mathrm{km} \\
\text { receive a one-time bonus of } 25 \% \text { of the car (maximum of about } € 5600 \text { ) }[29,40,41] \text {. }\end{array}$ & \\
\hline
\end{tabular}




\subsection{Infrastructure}

Within the EU28, there are widespread measures to promote EVs, which prioritize infrastructure use. In this sense, Directive 2014/94/UE of the European Parliament and the Council [42] on the deployment of alternative fuel infrastructure commits MSs to setting up sufficient charging points available to the public before 31 December, 2020. The aim of this directive is to facilitate circulation in densely populated areas especially in urban and suburban areas and networks determined by these MSs.

Malvik et al. [43] list several policy measures to promote BEV infrastructure. These include free parking in publicly-owned parking areas, the development of certain charging infrastructures, access to bus lanes for high occupancy vehicles and no road toll, and more. The development of dynamic tariff systems may be added in order to minimize charging costs and prevent grid congestion [44].

Table 7 outlines some of the main infrastructure development measures implemented by eighteen countries to promote EVs.

Low Emission Zones in Holland are also being introduced in an effort to improve air quality in cities [45]. Column 5 of Table 7 provides some examples of the largest urban areas in the Netherlands where such environmental zones have been introduced. The objective is to restrict the entry of non-'environmentally friendly' vehicles such as old diesel cars and large trucks.

In Sweden, several regional initiatives and regulatory changes have been introduced to promote EVs, which you can see in Table 7. In Germany, several cities have implemented special incentives for EV infrastructures, which are oriented toward converting its fleet into EVs. In Luxembourg, several measures have been included in the Global Mobility Strategy and the Transportation Sector Plan.

In the case of Ireland, the measures adopted imply that all counties and nearly $90 \%$ of major Irish cities have access to EV charging infrastructure. Pilot projects are operating in major Italian cities. In addition, projects related to infrastructure and eco-friendly mobility developed by local bodies may be financed by a government fund of $€ 380$ Mio.

In Spain, the program Movele was initiated between 2008 and 2011 with a budget of $€ 10$ Mio. Additionally, €35 Mio were invested in electric grid-related communication systems [46].

Portugal is a leader in EVs adaptation based on clean wind energy. This is due to the Renault-Nissan alliance. This arrangement also included the set-up of a national EVs infrastructure developer named MOBI.E [47].

The Greek Parliament passed a newly developed law for EV charging systems on the 30th of July in 2014. In addition to coordinating all of the parties involved, a special committee set up at the Ministry of Energy will also take charge of a public information campaign [48]. The new legislation considers that charging points do not need to have a particular license for supplying electrical energy. Therefore, this is going to boost the EV charging systems market [49].

In Malta, the government is installing a National Charging Network to provide the possibility to charge through public accessible car charging points. This will be interconnected by a network of strategically placed parking areas throughout the country [50]. This project is also being used to demonstrate how the Intelligent Transportation System Action Plan may be applied in the area of EV charging facilities. Additionally, these will be linked to the proposed Traffic Control Center hosting the Intelligent Traffic Management System so that it is able to monitor the performance of the vehicles as well as their charging status. Likewise, the plan aims to study the effectiveness of Full Electric Goods Carrying Vehicles. This information will improve data available in the Urban Traffic Management and Control and provide additional data for policy decision making [51].

Poland initiated its first "e-mobility" project in 2009. It was financed by the EU. It developed networks of charging points in five cities [52]. Recently, the authorities of some cities such as Warsaw, Krakow, and Poznan announced incentives to motivate drivers to use low-emission cars.

In February of 2014, the Electro-Mobility Development Plan (2014-2016) was approved by Latvia's Cabinet of Ministers. This plan was prepared by the Transportation Ministry and Road Traffic Safety Directorate, which is the first Electro-mobility plan developed in Latvia [53]. Public institutions, public 
persons, and those registered in Latvia as businesses may benefit from this plan through a support scheme for EV Charging Infrastructure (measure LV26 Electro-Mobility Development). This support has been provided for publicly available charging infrastructure with the project applicant required to be the owner of charging stations for at least five years after completing the project. Therefore, the applicant must have the right to use buildings and their land during this time [54]. The project's financial support rates over total eligible costs are $85 \%$ for public institutions, $70 \%$ for small and medium businesses, and $35 \%$ for large corporations with a maximum support for each charging station of $€ 31,300$.

In Lithuania, important changes are foreseen in highway rules as new signs associated with EVs such as EV charging stations and cases where road signs do not apply to EVs or their parking spaces. In addition, EVs will be allowed to drive on public transportation lanes, which will be marked with symbols of EVs [55]. The "Implementation Plan of the Strategy for National Climate Change Management Policy" includes the development of the infrastructure for EVs in cities [56].

Despite the interest in infrastructure in other countries, charging infrastructure is not a core activity at present in the UK even though some measures are being taken, which is reflected in Table 7 .

Table 7 summarizes the main infrastructure measures carried out in the EU28 to facilitate the use of EVs. As column 2 shows, the most popular measure is to expand the number of changing stations in use. 
Table 7. Measures to promote EVs infrastructure.

\begin{tabular}{|c|c|c|c|c|c|c|}
\hline Countries & Charging Points & Free Parking Places & Free Charging in Public Parking & Low Emissions Zones & No Road Toll & Fleet Promotion \\
\hline Austria & 1000 (Between 2007 and 2013). & & & & & $\begin{array}{l}€ 400,000 \text { are available for } \\
\text { companies, local } \\
\text { communities, and } \\
\text { associations if they } \\
\text { promote climate-friendly } \\
\text { traffic measures } \\
\text { particularly vehicle fleets } \\
\text { turning to alternative } \\
\text { drives such as Evs. }\end{array}$ \\
\hline Czech Republic & $\begin{array}{l}\text { 2011: began building a network } \\
\text { of public charging stations. } \\
\text { Prague: installed } 15 \text { and this } \\
\text { number is expected to increase } \\
\text { significantly [57]. } \\
\text { Points will be installed at the } \\
\text { main railway station and } \\
\text { Václav Havel Airport [58]. }\end{array}$ & $\begin{array}{l}\text { There are some free } \\
\text { parking zones for } \\
\text { electric cars [58]. }\end{array}$ & & $\begin{array}{l}\text { Prague and Klimkovice } \\
\text { are the most advanced } \\
\text { cities [45]. }\end{array}$ & & $\begin{array}{l}\text { Electric car-sharing pilot } \\
\text { program, which } \\
\text { introduces } 35 \text { electric cars } \\
\text { throughout the historic } \\
\text { city center. }\end{array}$ \\
\hline Denmark & & & Odense and Frederiksberg & & & \\
\hline Estonia & $\begin{array}{l}\text { Several plans have been vested } \\
\text { to support the introduction of } \\
\text { EVs [59], which allows a quick } \\
\text { charging network [29]. } \\
200 \text { will be installed along all } \\
\text { primary and secondary roads } \\
\text { at } 40-60 \text { km interval. } \\
\text { Local governments will also } \\
\text { install ordinary chargers [60]. }\end{array}$ & & & & & \\
\hline France & $\begin{array}{l}1250 \text { in } 20 \text { cities (until 2012). } \\
75,000 \text { public and } 900,000 \\
\text { private charging stations were } \\
\text { ready at } 2015 \text {. } \\
\text { 2020: } 400,000 \text { publics must be } \\
\text { installed. }\end{array}$ & & & & & $\begin{array}{l}\text { Local administrations } \\
\text { stimulate sales by } \\
\text { increasing the EV share of } \\
\text { their fleets. }\end{array}$ \\
\hline Germany & & & & & & $\begin{array}{l}\text { Berlin has begun } \\
\text { converting its fleet to EVs } \\
\text { The Initiative } 120 \text { project, } \\
\text { which is carried out at the } \\
\text { Berlin Police Department } \\
\text { testing alternative driving } \\
\text { systems for patrol cars. }\end{array}$ \\
\hline
\end{tabular}


Table 7. Cont.

\begin{tabular}{|c|c|c|c|c|c|c|}
\hline Countries & Charging Points & Free Parking Places & Free Charging in Public Parking & Low Emissions Zones & No Road Toll & Fleet Promotion \\
\hline Greece & $\begin{array}{l}13,000 \text { by } 2020 \text { [61]. The } \\
\text { planned program envisages an } \\
\text { integrated "Electro-Mobility } \\
\text { Network" performing as a } \\
\text { pilot project. }\end{array}$ & & & & & \\
\hline Hungary & $\begin{array}{l}\text { Budapest has installed } 10 \\
\text { public smart charging stations } \\
\text { linked to the marketplace [ } 62 \text { ]. } \\
68,000 \text { chargers will be } \\
\text { installed across the country by } \\
2020 \text { [63]. }\end{array}$ & & & & & \\
\hline Ireland & $\begin{array}{l}1000 \text { until } 2012 . \\
\text { Until 2014: projected the } \\
\text { installation of } 46 \text { fast charging } \\
\text { stations throughout the main } \\
\text { intercity itineraries and } \\
\text { principal transportation hubs } \\
\text { all along the island }[64,65] .\end{array}$ & & & & & \\
\hline Latvia & $\begin{array}{l}\text { Electro mobility Development } \\
\text { Plan (2014-2016) to support } \\
\text { publicly available charging } \\
\text { infrastructure. }\end{array}$ & & & & & \\
\hline Luxembourg & $\begin{array}{l}850 \text { must be installed in } 2020 \\
\text { [66]. }\end{array}$ & & $\begin{array}{l}\text { Building the first national platform } \\
\text { for EVs, whose major milestone is } \\
\text { the development of a smart energy } \\
\text { system by creating a public charging } \\
\text { infrastructure for EVs [67]. }\end{array}$ & & & $\begin{array}{l}\text { 2013: Private sector } \\
\text { Enovos Luxembourg and } \\
\text { the developer of mobility } \\
\text { projects City Mov' jointly } \\
\text { announced the launch of } \\
\text { the first car sharing } \\
\text { service whose customers } \\
\text { will be professionals and } \\
\text { municipal citizens. Its } \\
\text { fleet will be mainly } \\
\text { composed of "clean" } \\
\text { vehicles such as electric, } \\
\text { hybrid, or natural gas } \\
\text { vehicles [68]. }\end{array}$ \\
\hline Malta & $\begin{array}{l}100 \text { public smart charging and } \\
\text { smart parking points are going } \\
\text { to be deployed across Malta } \\
\text { and Gozo (at 2013). }\end{array}$ & & & & & \\
\hline
\end{tabular}


Table 7. Cont.

\begin{tabular}{|c|c|c|c|c|c|c|}
\hline Countries & Charging Points & Free Parking Places & Free Charging in Public Parking & Low Emissions Zones & No Road Toll & Fleet Promotion \\
\hline Netherlands & $\begin{array}{l}\text { More than } 5000 \text { by the end of } \\
2013 \text { (excluded private points). } \\
\text { A fast-charging network is } \\
\text { being rolled out along } \\
\text { highways and in parking [69]. }\end{array}$ & $\begin{array}{l}\text { Amsterdam, } \\
\text { Rotterdam (one year } \\
\text { of free parking) [70]. }\end{array}$ & Amsterdam. & $\begin{array}{l}\text { Amsterdam, The Hague, } \\
\text { Leiden, Rotterdam, and } \\
\text { Utrecht. }\end{array}$ & & \\
\hline Poland & There are a network. & In some towns. & & Specially in Krakow [71]. & & \\
\hline Portugal & 1300 until 2012 [47]. & & & & $\begin{array}{l}\text { Deduction of } 50 \% \\
\text { of the purchasing } \\
\text { price in Corporate } \\
\text { Tax if an old } \\
\text { vehicle is } \\
\text { scrapped. }\end{array}$ & \\
\hline Spain & $\begin{array}{l}\text { 343,350 must be installed in } \\
\text { 2014. } \\
\text { 2014: recharging-point- } \\
\text { installation objective was } \\
263,000 \text { for company fleets, } \\
62,000 \text { in homes, and } 6200 \\
\text { public road-side spaces. }\end{array}$ & $\begin{array}{l}\text { 12,150 public parking } \\
\text { spaces. }\end{array}$ & & & & \\
\hline Sweden & & $\begin{array}{l}\text { Arlanda and } \\
\text { Gothenburg [39]. }\end{array}$ & Stockholm (70 points). & & $\begin{array}{l}\text { Alternative } \\
\text { vehicles } \\
\text { matriculated by } \\
2008 \text { enjoy a } \\
\text { congestion toll } \\
\text { road exemption in } \\
\text { Stockholm } \\
\end{array}$ & \\
\hline $\begin{array}{l}\text { United } \\
\text { Kingdom }\end{array}$ & $\begin{array}{l}\text { Provides } € 36 \text { Mio for three EV } \\
\text { hubs (in Milton Keynes, } \\
\text { London, and the North East). } \\
\text { Future developments will be } \\
\text { plans to install } 11,000 \\
\text { recharging points [72]. }\end{array}$ & & & & & \\
\hline
\end{tabular}




\subsection{Research Financing and Communication Programs}

The 2010 European Parliament Resolution regarding vehicles establishes that innovating propulsion systems, which are both electric and hybrid, will help guarantee future competitiveness of the automobile industry [73]. This Resolution underlines that EVs represent a technological advancement that requires the integration of certain innovation strategies and technological developments through adequate financing and the promotion of R\&D. In this regard, it would be beneficial for public aid packages offered to businesses to be linked to a set of clear-cut objectives with social, technological, economic, and environmental references. Noteworthy public aid packages include those from Austria, Germany, Denmark, Finland, France, Italy, Spain, and the UK. The main aspects are provided in column 2 of Table 8.

Together with the support measures for R\&D, some MSs have approved measures that focus on improving consumer perception of the advantages of EVs. This is not limited to the European Union. In fact, a range of transportation labeling activities is taking place in International Energy Agency (IEA) member countries including voluntary and mandatory vehicle and tire labeling schemes. Labels are assigned to vehicles based on fuel consumption and emissions. Despite its limited use, this is a very important measure in line with the available literature. The results offered by Krause et al. [74] pointed out that people have a high degree of misperception about the basic features of EVs including their appearance, upfront and operating costs, and driving range. These results are in line with those from Carley et al. [13].

Table 8 shows EU28 countries that have developed the most relevant measures oriented toward R\&D and consumer awareness.

Table 8. Measures oriented towards R\&D and consumer awareness.

\begin{tabular}{|c|c|c|}
\hline Countries & Research Financing & Communications Programs \\
\hline Austria & $\begin{array}{l}\text { Companies, municipalities, and cities also receive } \\
\text { financial support to develop and implement } \\
\text { environmentally-friendly movability management, } \\
\text { which adds solutions that are more effective in traffic. } \\
\text { In this regard, funding rates are } 20 \% \text { of eligible costs } \\
\text { of companies and } 40 \% \text { of eligible costs of cities, } \\
\text { municipalities, and regions [35]. }\end{array}$ & $\begin{array}{l}\text { Thaler [36] pointed out that the 'klima:aktiv } \\
\text { program' including significant information } \\
\text { and important awareness campaigns } \\
\text { oriented to informing the general } \\
\text { population as well as the media and } \\
\text { opinion leaders. }\end{array}$ \\
\hline Belgium & & $\begin{array}{l}\text { New laws have required that dealers must } \\
\text { show a fuel economy label to each model } \\
\text { for sale, which helps potential purchasers } \\
\text { learn about the effect on pollution of every } \\
\text { vehicle by using a simple colored schema. A } \\
\text { red color is assigned for the most highly } \\
\text { polluting vehicles while a green color is } \\
\text { assigned for vehicles with the lowest } \mathrm{CO}_{2} \\
\text { emission levels [32]. }\end{array}$ \\
\hline Denmark & $\begin{array}{l}\text { The project 'Test-an-EV': consists in } 2400 \text { families that } \\
\text { test in turns } 300 \text { EVs for day-to-day usage in order to } \\
\text { analyze user experiences with EVs and disclose } \\
\text { driving and charging patterns [43]. }\end{array}$ & \\
\hline Estonia & & $\begin{array}{l}\text { ELMO program promotes EVs with the } \\
\text { purpose of accomplishing the development } \\
\text { of more ecological and environmentally } \\
\text { friendly cities [75]. It has developed a } \\
\text { Demo project: } 507 \text { EVs received from } \\
\text { Mitsubishi were given to use by social } \\
\text { workers and the public sector. } \\
\text { The goal of ELMO Rental is to make using } \\
\text { EVs more popular and it provided an } \\
\text { opportunity for everyone to try driving an } \\
\text { EV [59]. }\end{array}$ \\
\hline
\end{tabular}


Table 8. Cont.

\begin{tabular}{|c|c|c|}
\hline Countries & Research Financing & Communications Programs \\
\hline Finland & $\begin{array}{l}\text { TransEco investigation program (2009-2013): was } \\
\text { oriented to the development of technology for } \\
\text { enhanced energetic efficiency and the reduction } \\
\text { on emissions level on highway } \\
\text { transportation [30]. }\end{array}$ & $\begin{array}{l}\text { Passenger car energy label: facilitates the } \\
\text { potential buyer to compare the different } \\
\mathrm{CO}_{2} \text { emission levels for each vehicle as well } \\
\text { as the diverse levels of fuel consumption. } \\
\text { These labels are recommended but is not } \\
\text { mandatory. Cars are distributed into } \\
\text { categories (A to } \mathrm{G} \text { ) on the basis of fuel } \\
\text { consumption and emissions. Best categories } \\
\text { are those from A to } \mathrm{C} \text { and satisfy the goal of } \\
\text { not exceeding the limit of } 130 \mathrm{~g} / \mathrm{km} \mathrm{CO} \mathrm{CO}_{2} \\
\text { emissions established by the EU. }\end{array}$ \\
\hline France & $\begin{array}{l}\text { The programs for research, experimentation, and } \\
\text { innovation in land transportation (PREDIT) } \\
\text { financed EV research projects for a net worth of } \\
€ 107 \text { Mio (2009-2010). The state controlled Fonds } \\
\text { Stratégique d'Investissement (FSI) provides loans } \\
\text { for innovative R\&D projects. }\end{array}$ & \\
\hline Germany & $\begin{array}{l}\text { Has destined } € 2 \text { billion for promoting the } \\
\text { introduction of EVs including support focused on } \\
\text { developing improved technologies toward EVs, } \\
\text { research in battery technologies, R\&D of } \\
\text { intelligent supply networks, and standardization } \\
\text { projects. }\end{array}$ & \\
\hline Italy & $\begin{array}{l}\text { Approved support and co-finance of up to } 50 \% \text { of } \\
\text { projects promoting electro-mobility. }\end{array}$ & \\
\hline Netherlands & & $\begin{array}{l}\text { Oriented to promote the concept of } \\
\text { 'eco-driving' for all types of vehicle drivers } \\
\text { A list of best practices are incorporated in } \\
\text { regular driving lessons [76]. }\end{array}$ \\
\hline Poland & & $\begin{array}{l}\text { "Mobilny Kraków" is a social campaign } \\
\text { promoting the use of clean vehicles. }\end{array}$ \\
\hline Spain & $\begin{array}{l}\text { Provides } € 140 \text { Mio for industrialization support } \\
\text { and } R \& D \text { and } € 173 \text { Mio to priority } R \& D \text { lines. }\end{array}$ & \\
\hline $\begin{array}{l}\text { United } \\
\text { Kingdom }\end{array}$ & $\begin{array}{l}€ 170 \text { Mio are provided to market players for R\&D } \\
\text { activities into "low carbon vehicles". }\end{array}$ & \\
\hline
\end{tabular}

\section{Discussion}

MSs offer both financial and non-financial incentives to promote electro-mobility. These include tax credits (discounted vehicle license, registration fees, and more), purchase subsidies, subsidies for the installation of charging stations, high occupancy vehicles lane access and free parking access, R\&D projects funding, and educational programs. The available literature sheds some light on the subject, but not a significant amount of information about the variables that include the use of some type of promotional measure. Pablo-Romero et al. [77], Sánchez-Braza et al. [78], and Wang [79] show that the population size is a driver when establishing environmental measures including the promotion of EVs.

The review carried out in this article shows that more than $60 \%$ of the EU28 population live in a MSs where EVs pay no registration tax due to the existence of an ample $\mathrm{CO}_{2}$ emission threshold that is below the limit for taxation. However, only five MSs establish fiscal incentives for commercially used EVs. This limited use of fiscal incentives should be reconsidered since the use of commercial vehicles is more intense than private vehicles and, therefore, these consume more fuel and are emitting more GHG.

The most popular measure using infrastructure to promote the use of battery electric vehicles (BEVs) is favoring the installation of charging stations. Yet, in most MSs, charging stations are limited to the major cities. Estonia represents the only exception since it has installed charging stations on highways. As discussed in Section 3, the integration of charging stations in Smart Grid Systems has 
never been contemplated. The second, most extended measure is free parking for EVs. This measure is also limited especially in large cities. Together with the two previous measures, two MSs (Holland and the Czech Republic) have low carbon zones. Although it is not exactly a promotional measure based on the use of infrastructures, this section has included public EV fleets.

Undoubtedly, the penetration of EVs in each country does not depend solely on the promotional measures implemented by the public sector. Nevertheless, there is room for discussion when the EV registration data is available. Table 9 allows for this discussion. No statistics are available that allow us to create a temporal series of numbers for EVs in the EU28. Consequently, the conclusions extracted must be considered with care. This information can only be established for the 2013-2015 period based on the data supplied by ACEA $[26,80,81]$ and not for all of the MSs within the EU28. For a fine-tuned analysis, data for the EVs fleet market share in each country based on the total fleet has been included along with the number of EVs per thousand inhabitants and the variation rates of both variables from 2013 to 2015.

Based on Table 9, it could be said that the Netherlands, France, Germany, and the UK are the countries with the greatest success in the penetration of EVs considering their joint market share and the number of EVs per 1000 inhabitants (see Figures 1 and 2). In all cases, the leading countries in the use of EVs greatly tap into public promotional measures oriented toward favoring their use.

Both the Netherlands and France have changed their registration taxes to incorporate an environmental criterion (level of GHG emissions) when calculating the invoice. In both cases, EVs are tax exemptions. Germany however, uses the ownership tax by which it establishes a fiscal incentive for EV with a 10-year exemption. It must also be stated that, together with the Netherlands, Germany is one of the few MSs that favors the use of EVs for commercial purposes since it includes the emission volume in the invoice calculation for the ownership tax. In this regard, it must be highlighted that both counties incorporate incentives for a personal income tax that favors the acquisition of EVs. In the case of incentives implemented through infrastructure measures, France appears to be the first country that expanded charging stations and delimited low emissions zones using infrastructure incentives. French authorities also make use of financial incentives to promote the purchase of EVs. However, Sierzchula et al. [16] state that there are other factors besides the financial inducements that incentivize the purchase of EVs. Lastly, while France and Germany fund R\&D projects linked to EVs - the automobile industry is a major industry in both countries-the Netherlands sponsors communications programs to promote the eco-driving culture.

One specific comment regarding the limited use that MSs make of information programs goes against the recommendations of recent literature. Krause et al. [74] found that potential buyers have limited knowledge of public promotional measures, which restricts efficiency and shows that this information has not been correctly or adequately presented. Along this same line, education programs have plenty to do since potential consumers have, for the most part, incorrect knowledge about the basic cost and operating features of EVs. This degree of misperception decreases with the potential buyer's educational level. All else being equal, a potential purchaser with higher education expresses a greater stated intention to purchase. 
Table 9. Main figures for EVs fleet in EU28 (2013-2015).

\begin{tabular}{|c|c|c|c|c|c|c|c|c|c|c|c|c|c|}
\hline Country & $\begin{array}{l}\text { EVs } \\
2013\end{array}$ & $\begin{array}{c}\text { Market } \\
\text { Share (\%) }\end{array}$ & $\begin{array}{l}\text { EVs per } \\
1000 \text { hab. }\end{array}$ & $\begin{array}{l}\text { EVS } \\
2014\end{array}$ & $\begin{array}{c}\text { Market } \\
\text { Share (\%) }\end{array}$ & $\begin{array}{l}\text { EVs per } \\
1000 \text { hab. }\end{array}$ & $\begin{array}{l}\text { EVs } \\
2015\end{array}$ & $\begin{array}{c}\text { Market } \\
\text { Share (\%) }\end{array}$ & $\begin{array}{l}\text { EVs per } \\
1000 \text { hab. }\end{array}$ & $\begin{array}{l}\text { EVs per GDP in } \\
\text { Miles of } \\
\text { Millions }\end{array}$ & $\begin{array}{c}\text { EVs per } \\
\text { Total Miles } \\
\text { of Vehicles }\end{array}$ & $\begin{array}{c}\text { 2013-2015 } \\
\text { Market Share } \\
\text { Change (\%) }\end{array}$ & $\begin{array}{c}\text { EVs per } \\
1000 \text { hab. } \\
\text { Change (\%) }\end{array}$ \\
\hline Austria & 3227 & $5.85 \%$ & 0.38 & 3641 & $4.83 \%$ & 0.43 & 2575 & $2.05 \%$ & 0.30 & 7.47 & 0.54 & $-64.95 \%$ & $-21.13 \%$ \\
\hline Belgium & 819 & $1.49 \%$ & 0.07 & 2032 & $2.70 \%$ & 0.18 & 4073 & $3.24 \%$ & 0.36 & 9.93 & 0.72 & $118.45 \%$ & $389.62 \%$ \\
\hline Bulgaria & 1 & $0.00 \%$ & 0.00 & 2 & $0.00 \%$ & 0.00 & 40 & $0.03 \%$ & 0.01 & 0.88 & 0.01 & $1657.03 \%$ & $3947.01 \%$ \\
\hline Croatia * & N/A & N/A & N/A & $\mathrm{N} / \mathrm{A}$ & N/A & N/A & N/A & $\mathrm{N} / \mathrm{A}$ & N/A & N/A & $\mathrm{N} / \mathrm{A}$ & N/A & $\mathrm{N} / \mathrm{A}$ \\
\hline Cyprus* & $\mathrm{N} / \mathrm{A}$ & $\mathrm{N} / \mathrm{A}$ & $\mathrm{N} / \mathrm{A}$ & $\mathrm{N} / \mathrm{A}$ & N/A & N/A & N/A & N/A & N/A & N/A & N/A & N/A & N/A \\
\hline $\begin{array}{c}\text { Czech } \\
\text { Republic }\end{array}$ & 475 & $0.86 \%$ & 0.05 & 583 & $0.77 \%$ & 0.06 & 856 & $0.68 \%$ & 0.08 & 5.08 & 0.17 & $-20.84 \%$ & $79.87 \%$ \\
\hline Denmark & 650 & $1.18 \%$ & 0.12 & 1612 & $2.14 \%$ & 0.29 & 3701 & $2.95 \%$ & 0.66 & 13.62 & N/A & $150.11 \%$ & $464.65 \%$ \\
\hline Estonia & 150 & $0.27 \%$ & 0.03 & 402 & $0.53 \%$ & 0.09 & 45 & $0.04 \%$ & 0.01 & 2.21 & 0.07 & $-86.82 \%$ & $-70.08 \%$ \\
\hline Finland & 218 & $0.40 \%$ & 0.04 & 440 & $0.58 \%$ & 0.08 & 724 & $0.58 \%$ & 0.13 & 3.45 & 0.22 & $45.88 \%$ & $228.97 \%$ \\
\hline France & 9622 & $17.45 \%$ & 0.15 & 12,488 & $16.58 \%$ & 0.19 & 23,296 & $18.56 \%$ & 0.35 & 10.60 & 0.72 & $6.35 \%$ & $139.93 \%$ \\
\hline Germany & 7706 & $13.97 \%$ & 0.09 & 13,118 & $17.41 \%$ & 0.16 & 21,407 & $17.05 \%$ & 0.27 & 7.03 & 0.47 & $22.02 \%$ & $182.31 \%$ \\
\hline Greece & 4 & $0.01 \%$ & 0.00 & 64 & $0.08 \%$ & 0.01 & 70 & $0.06 \%$ & 0.01 & 0.40 & 0.01 & $668.70 \%$ & $1663.48 \%$ \\
\hline Hungary & 16 & $0.03 \%$ & 0.00 & 43 & $0.06 \%$ & 0.00 & 132 & $0.11 \%$ & 0.01 & 1.19 & 0.04 & $262.39 \%$ & $728.81 \%$ \\
\hline Ireland & 50 & $0.09 \%$ & 0.01 & 256 & $0.34 \%$ & 0.06 & 583 & $0.46 \%$ & 0.13 & 2.22 & 0.28 & $412.17 \%$ & $1063.02 \%$ \\
\hline Italy & 1174 & $2.13 \%$ & 0.02 & 1473 & $1.96 \%$ & 0.02 & 2539 & $2.02 \%$ & 0.04 & 1.54 & N/A & $-5.00 \%$ & $111.80 \%$ \\
\hline Latvia & 13 & $0.02 \%$ & 0.01 & 391 & $0.52 \%$ & 0.20 & 139 & $0.11 \%$ & 0.07 & 5.72 & 0.20 & $369.67 \%$ & $989.66 \%$ \\
\hline Lithuania ** & $\mathrm{N} / \mathrm{A}$ & N/A & N/A & N/A & N/A & N/A & 34 & $0.03 \%$ & 0.01 & 0.91 & 0.03 & N/A & N/A \\
\hline Luxembourg * & $\mathrm{N} / \mathrm{A}$ & N/A & N/A & N/A & N/A & N/A & N/A & N/A & N/A & N/A & N/A & N/A & N/A \\
\hline Malta * & N/A & N/A & N/A & N/A & N/A & N/A & N/A & N/A & N/A & N/A & N/A & N/A & N/A \\
\hline Netherlands & 22,495 & $40.79 \%$ & 1.34 & 12,920 & $17.15 \%$ & 0.77 & 16,852 & $13.42 \%$ & 1.00 & 24.42 & 2.08 & $-67.09 \%$ & $-25.52 \%$ \\
\hline Poland & 1900 & $3.45 \%$ & 0.05 & 3968 & $5.27 \%$ & 0.10 & 3328 & $2.65 \%$ & 0.09 & 7.74 & 0.16 & $-23.06 \%$ & $75.31 \%$ \\
\hline Portugal & 221 & $0.40 \%$ & 0.02 & 289 & $0.38 \%$ & 0.03 & 868 & $0.69 \%$ & 0.08 & 4.83 & 0.18 & $72.52 \%$ & $297.30 \%$ \\
\hline Romania & 4 & $0.01 \%$ & 0.00 & 7 & $0.01 \%$ & 0.00 & 44 & $0.04 \%$ & 0.00 & 0.27 & 0.01 & $383.18 \%$ & $1006.12 \%$ \\
\hline $\begin{array}{c}\text { Slovak } \\
\text { Republic }\end{array}$ & 136 & $0.25 \%$ & 0.03 & 169 & $0.22 \%$ & 0.03 & 131 & $0.10 \%$ & 0.02 & 1.66 & 0.06 & $-57.69 \%$ & $-3.78 \%$ \\
\hline Slovenia * & N/A & N/A & N/A & N/A & N/A & N/A & N/A & N/A & N/A & N/A & N/A & N/A & N/A \\
\hline Spain & 883 & $1.60 \%$ & 0.02 & 1405 & $1.87 \%$ & 0.03 & 2345 & $1.87 \%$ & 0.05 & 2.17 & 0.10 & $16.65 \%$ & $167.50 \%$ \\
\hline Sweden & 1547 & $2.81 \%$ & 0.16 & 4667 & $6.20 \%$ & 0.48 & 6819 & $5.43 \%$ & 0.70 & 15.19 & 1.46 & $93.62 \%$ & $333.27 \%$ \\
\hline $\begin{array}{c}\text { United } \\
\text { Kingdom }\end{array}$ & 3833 & $6.95 \%$ & 0.06 & 15,361 & $20.39 \%$ & 0.24 & 34,938 & $27.83 \%$ & 0.54 & 13.38 & 1.15 & $300.39 \%$ & $800.97 \%$ \\
\hline Total & 55,144 & $100 \%$ & & 75,331 & $100 \%$ & & 125,539 & $100 \%$ & & 8.47 & 1.23 & & \\
\hline
\end{tabular}

* Not available information; ${ }^{* *}$ Information available only for 2015. Source: $[26,33,80,81]$. 


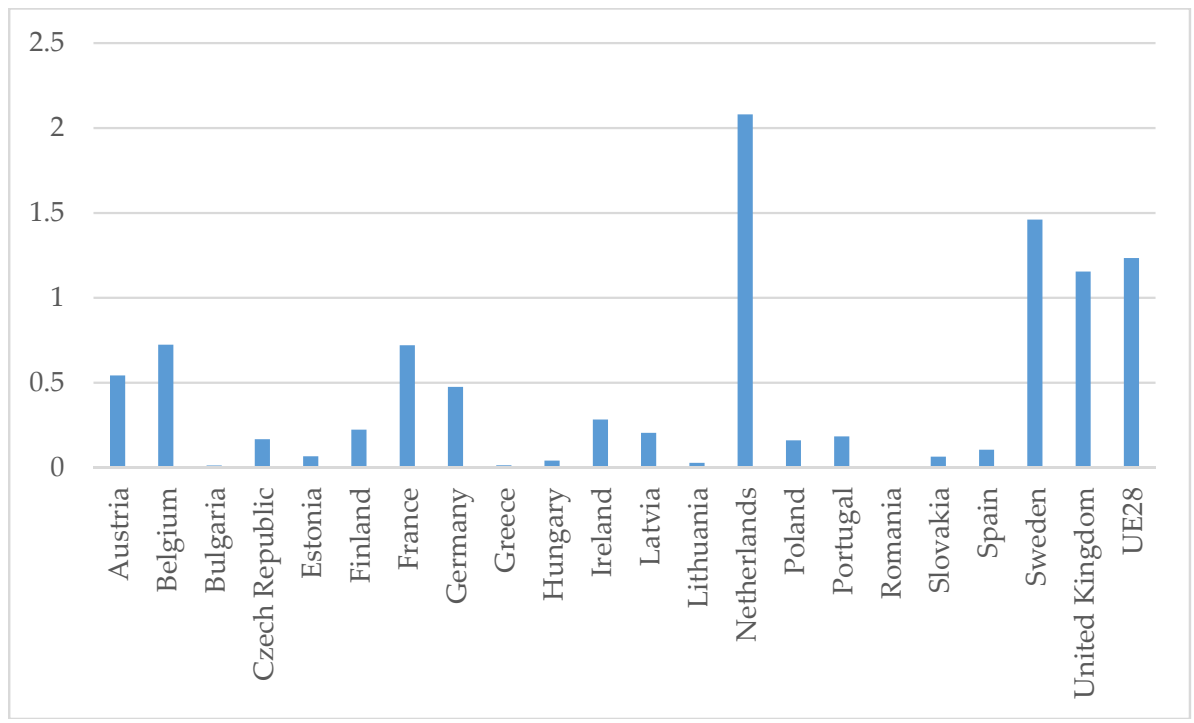

Figure 1. Ratio EVs per total vehicles (2015).

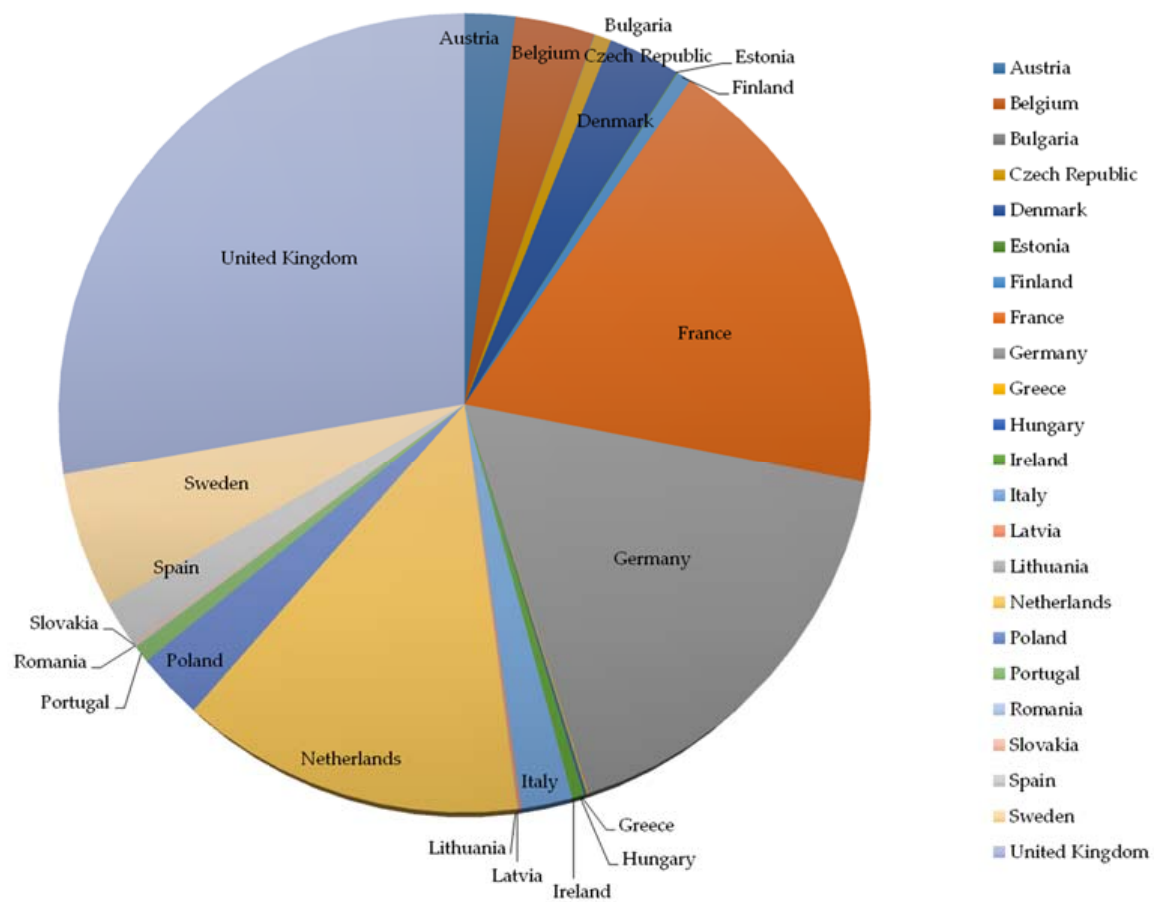

Figure 2. EVs fleet market share in each country based on the total fleet (2015).

\section{Conclusions and Policy Implications}

Despite the misperceptions, potential EV purchasers perceive the cost premium, range limitation, and recharging time of EVs as disadvantages compared to other vehicle types. Offering MSs the possibility to use a wide range of policy instruments to promote electro-mobility in the context of H2020 strategy is important. These policy instruments to promote the use of EVs are largely used in EU28 to facilitate this decision similarly to those used to promote RES for other uses.

Figures shown above led us to conclude that the most important policy instruments to promote the use of EVs are tax and infrastructure measures along with financial incentives for purchasing and supporting R\&D projects. Despite the scarcity of EV registration data, the available information allows us to conclude that higher penetration levels of EVs appear in countries where the registration tax, the 
ownership tax, or both taxes have developed into a partial green tax by including $\mathrm{CO}_{2}$ emissions in the calculation of the final invoice. The countries with a more intense use of EVs also fund charging stations to facilitate electro-mobility. In the case of the the automobile industry being relevant at the national level, public funding also supports R\&D projects by focusing on EV deployment.

After reviewing the most important policy instruments to promote the use of EVs in line with the available literature, some policy recommendations might be considered.

The vehicle age could be included as an additional parameter to calculate the final invoice for ownership tax. This could facilitate the replacement of older and higher polluting vehicles by newer and less contaminating EVs.

The ownership tax applied to commercial vehicles could include $\mathrm{CO}_{2}$ emission levels when calculating the final invoice. This is particularly important because such vehicles are the most fuel demanding and the most responsible for $\mathrm{CO}_{2}$ emissions when using internal combustion motors. Growth in e-commerce ought to lead to increasing use of EVs for parcel deliveries in urban areas. Measures to support EVs could be seen as a part of the effort required to meet the delivery services offered by e-retailers.

EVs could become part of future smart electricity systems in a twofold sense. First of all, their batteries could be considered as a (disperse) storage system for better management of demand peaks. Lessons learned from vehicle to grid pilot projects would be useful. Second, if a dynamic tariff system is deployed at the national level, different prices of electricity for charging EVs could reduce the risk of disruption by enhancing power capacity.

In addition, communication programs could play a crucial role in promoting electro-mobility through two ways. First, misperceptions of the main advantages of EVs could be reduced through adequate information programs co-funded together with private companies. Second, remarkable efforts in communicating available public incentives could help to shift potential consumers to EVs from other, more contaminating options.

Author Contributions: Conceptualization, J.M.C. and A.S.-B. Investigation, J.M.C., A.S.-B. and T.S.-D. Resources, J.M.C., A.S.-B., and T.S.-D. Writing-Original Draft Preparation, J.M.C., A.S.-B., and T.S.-D. Writing-Review \& Editing, A.S.-B. and T.S.-D. Supervision, J.M.C. and A.S.-B. Project Administration, J.M.C.

Funding: This research received no external funding.

Acknowledgments: The authors wish to acknowledge the funding provided by the Andalusian Regional Government (project SEJ-132), the "Cátedra de Economía de la Energía y del Medio Ambiente (Universidad de Sevilla-Red Eléctrica de España)", Spain's Ministry of Economy and Competitiveness (ECO2014-56399-R Project), and from Department of Economic Analysis and Political Economy (Universidad de Sevilla). The first author also acknowledges the funding provided by the Universidad Autónoma de Chile (Chile).

Conflicts of Interest: The authors declare no conflict of interest.

\section{References}

1. European Commission. Clean Power for Transport: A European Alternative Fuels Strategy Communication from the Commission to the European Parliament, the Council, the European Economic and Social Committee and the Committee of the Regions; European Commission: Brussels, Belgium, 2013; Available online: http: / / cor.europa.eu/en/activities/stakeholders/Documents/com2013-17.pdf (accessed on 1 June 2017).

2. European Climate Foundation (ECF). Annual Report 2012; European Climate Foundation: The Hague, The Netherlands, 2013; Available online: http:/ / www.europeanclimate.org/documents /2012Report.pdf (accessed on 1 June 2017).

3. European Commission. A European Economic Recovery Plan. Communication from the Commission; European Commission: Brussels, Belgium, 2008; Available online: http:/ / ec.europa.eu/economy_finance/ publications/publication13504_en.pdf (accessed on 1 June 2017).

4. European Council. Conclusions on 2030 Climate and Energy Policy Framework. SN 79/14. 2014. Available online: https://www.consilium.europa.eu/uedocs/cms_data/docs/pressdata/en/ec/145356.pdf (accessed on 7 May 2017). 
5. European Commission. Roadmap to a Single European Transport Area-Towards a Competitive and Resource Efficient Transport System; White Paper; European Commission: Brussels, Belgium, 2011; Available online: http:/ / eur-lex.europa.eu/legal-content/EN/TXT/PDF/?uri=CELEX:52010DC0639\&from=EN (accessed on 3 July 2017).

6. Hannan, M.A.; Azidin, F.A.; Mohamed, A. Hybrid electric vehicles and their challenges: A review. Renew. Sustain. Energy Rev. 2014, 29, 135-150. [CrossRef]

7. Ma, H.; Balthasar, F.; Tait, N.; Riera-Palou, X.; Harrison, A. A new comparison between the life cycle greenhouse gas emissions of battery electric vehicles and internal combustion vehicles. Energy Policy 2012, 44, 160-173. [CrossRef]

8. Van Mierlo, J.; Maggeto, G.; Lataire, P. Which energy source for road transport in the future? A comparison of battery, hybrid and fuel cell vehicles. Energy Convers. Manag. 2006, 47, 2748-2760. [CrossRef]

9. Buenstorf, G.; Cordes, C. Can sustainable consumption be learned? A model of cultural evolution. Ecol. Econ. 2008, 67, 646-657. [CrossRef]

10. Perujo, A.; Ciuffo, B. The introduction of electric vehicles in the private fleet: Potential impact on the electric supply system and on the environment. A case study for the Province of Milan, Italy. Energy Policy 2010, 38, 4549-4561. [CrossRef]

11. Camus, C.; Farias, T.; Esteves, J. Potential impacts assessment of plug-in electric vehicles on the Portuguese energy market. Energy Policy 2011, 39, 5883-5897. [CrossRef]

12. Eurostat. New Registrations of Passenger Cars, Motor Coaches, Buses and Trolley Buses, by Type of Vehicle and Alternative Motor Energy. 2016. Available online: http:/ / ec.europa.eu/eurostat/web/transport/data/ database (accessed on 4 May 2016).

13. Carley, S.; Krause, R.M.; Lane, B.W.; Graham, J.D. Intent to purchase a plug-in electric vehicle: A survey of early impressions in large US cites. Transp. Res. Part D Transp. Environ. 2013, 18, 39-45. [CrossRef]

14. Lam, A.; Lee, S.; Mercure, J.F.; Cho, Y.; Lin, C.H.; Pollitt, H.; Chewpreecha, U.; Billington, S. Policies and predictions for a low-carbon transition by 2050 in passenger vehicles in East Asia: Based on an analysis using the E3ME-FTT model. Sustainability 2018, 10, 1612. [CrossRef]

15. Coffman, M.; Bernstein, P.; Wee, S. Electric vehicles revisited: A review of factors that affect adoption. Transp. Rev. 2017, 37, 79-93. [CrossRef]

16. Sierzchula, W.; Bakker, S.; Maat, K.; van Wee, B. The influence of financial incentives and other socio-economic factors on electric vehicle adoption. Energy Policy 2014, 68, 183-194. [CrossRef]

17. Graham-Rowe, E.; Gardner, B.; Abraham, C.; Skippon, S.; Dittmar, H.; Hutchins, R.; Stannard, J. Mainstream consumers driving plug-in battery-electric and plug-in hybrid electric cars: A qualitative analysis of responses and evaluations. Transp. Res. Part A Policy Pract. 2012, 46, 140-153. [CrossRef]

18. Ramsey, M. Ford Reveals How Much Electric-Car Batteries Cost. The Wall Street Journal. 17 April 2012. Available online: http:/ /blogs.wsj.com/drivers-seat/2012/04/17/ford-reveals-how-much-electric-carbatteries-cost/ (accessed on 20 February 2016).

19. Transportation Electrification Panel (TEP). Plug-in Electric Vehicles: A Practical Plan for Progress; Transportation Electrification Panel, School of Public and Environmental Affairs at Indiana University: Bloomington, Indiana, 2011; Available online: http:/ / www.indiana.edu/ cree/pdf/TEP\%20Report.pdf (accessed on 5 May 2017).

20. Hidrue, M.K.; Parsons, G.R.; Kempton, W.; Gardner, M.P. Willingness to pay for electric vehicles and their attributes. Resour. Energy Econ. 2011, 33, 686-705. [CrossRef]

21. Cansino, J.M.; Pablo-Romero, M.P.; Román, R.; Yñiguez, R. Tax incentives to promote green electricity: An overview of EU-27 countries. Energy Policy 2010, 38, 6000-6008. [CrossRef]

22. Cansino, J.M.; Pablo-Romero, M.P.; Román, R.; Yñiguez, R. Promoting renewable energy sources for heating and cooling in EU-27 countries. Energy Policy 2011, 39, 3803-3812. [CrossRef]

23. Cansino, J.M.; Pablo-Romero, M.P.; Román, R.; Yñiguez, R. Promotion of biofuel consumption in the transport sector: An EU-27 perspective. Renew. Sustain. Energy Rev. 2012, 16, 6013-6021. [CrossRef]

24. ACEA Tax Guide 2012; European Automobile Manufacturers Association: Brussels, Belgium, 2012.

25. Donat, L.; Eberle, A.; Velten, E.K.; Duwe, M.; Maroulis, G. Assessment of Climate Change Policies in the Context of the European Semester. Country Report: Cyprus (Covering the Period between February 2013 and November 2013); Ecologic Institute and Eclareon: Berlin, Germany, 2014; Available online: http:/ / ecologic.eu/sites/files / publication/2014/countryreport_cy_ecologiceclareon_jan2014_0.pdf (accessed on 3 June 2017). 
26. ACEA Tax Guide 2014; European Automobile Manufacturers Association: Brussels, Belgium, 2014.

27. Duwe, M.; Smith, L.O.; Donat, L.; Velten, E.K.; Jirouš, F. Assessment of Climate Change Policies in the Context of the European Semester. Country Report: Bulgaria (Covering the period between February 2013 and November 2013); Ecologic Institute and Eclareon: Berlin, Germany, 2014; Available online: http:/ / ecologic.eu/sites / files / publication/2014/countryreport_bg_ecologiceclareon_jan2014_0.pdf (accessed on 20 July 2017).

28. Van Essen, H.; Nelissen, D.; Smit, M.; van Grinsven, A.; Aarnink, S.; Breemersch, T.; Martino, A.; Rosa, C.; Parolin, R.; Harmsenm, J. An Inventory of Measures for Internalising External Costs in Transport; Directorate-General for Mobility and Transport, European Commission: Brussels, Belgium, 2012; Available online: http:/ / www.cedelft.eu/publicatie/an_inventory_of_measures_for_internalising_external_costs_ in_transport/1334 (accessed on 1 January 2016).

29. Thiel, C.; Krause, J.; Dilara, P. Electric Vehicles in the EU from 2010 to 2014 Is Full Scale Commercialisation Near? JRC Science and Political Report; European Commission, Joint Research Centre, Institute for Energy and Transport: Brussels, Belgium, 2015.

30. Clean Vehicle Finland. Information per Country and EU Policy-Finland; European Commission and the Executive Agency for Competitiveness and Innovation: Brussels, Belgium, 2015; Available online: http: / / www.cleanvehicle.eu/info-per-country-and-eu-policy/memberstates/finland/national-level/ (accessed on 2 September 2015).

31. Electric Vehicle Grant Scheme Overview; Sustainable Energy Authority of Ireland (SEAI): Dublin, Ireland, 2015. Available online: http:/ / www.seai.ie/Grants/Electric_Vehicle_Grant_Scheme/I_am_a_consumer/Benefits_ of_Buying_an_Electric_Vehicle/ (accessed on 4 December 2015).

32. Clean Vehicle Belgium. Information per Country and EU Policy-Belgium; European Commission and the Executive Agency for Competitiveness and Innovation: Brussels, Belgium, 2015; Available online: http:// www.cleanvehicle.eu/info-per-country-and-eu-policy/memberstates/belgium/national-level/ (accessed on 15 September 2015).

33. Eurostat. Key Statistics. Main Scenario—Population on 1st January by Age and Sex [proj_13npms]. 2015. Available online: http:/ / ec.europa.eu/eurostat/web/products-datasets/-/ proj_13npms (accessed on 15 December 2015).

34. Donat, L.; Velten, E.K.; Duwe, M.; Najdawi, C.; Wevers, M. Assessment of Climate Change Policies in the Context of the European Semester. Country Report: Belgium (Covering the Period between February 2013 and November 2013); Ecologic Institute and Eclareon: Berlin, Germany, 2014; Available online: http:/ / ecologic.eu/sites / files/publication/2014/countryreport_be_ecologiceclareon_jan2014_0.pdf (accessed on 3 April 2017).

35. Klimaaktiv. Annual Report 2011. Network for Change; Austrian Energy Agency Klimaaktiv Management: Vienna, Austria, 2011; Available online: http://www.klimaaktiv.at/dms/klimaaktiv/publikationen/ klimaaktiv/annualreport2011/Annual-Report-2011/Annual\%20Report\%202011.pdf?1=1 (accessed on 2 May 2017).

36. Thaler, R. Austrian Showcase Klimaaktiv Mobil-National Program for Environmentally Friendly Mobility; Austrian Ministry for Agriculture, Forestry, Environment and Water Management, Head of Division Mobility Transport Noise: Vienna, Austria, 2014; Available online: http: / / www.unece.org/fileadmin/DAM/env / documents/2014/AIR/WGSR/1_Thaler_BMLFUW_short_ engl_version_klimaaktivmobil_LRTAP_UNECE_fin.pdf (accessed on 2 April 2017).

37. Clean Vehicle Bulgaria. Information per Country and EU Policy-Bulgaria; European Commission and the Executive Agency for Competitiveness and Innovation: Brussels, Belgium, 2015; Available online: http:// www.cleanvehicle.eu/info-per-country-and-eu-policy/memberstates/bulgaria/national-level/ (accessed on 7 September 2015).

38. Clean Vehicle Cyprus. Information per Country and EU Policy-Cyprus; European Commission and the Executive Agency for Competitiveness and Innovation: Brussels, Belgium, 2015; Available online: http: / / www.cleanvehicle.eu/info-per-country-and-eu-policy/memberstates/cyprus/national-level/ (accessed on 10 September 2015).

39. Albrecht, M.; Nilsson, M.; Åkerman, J. Electrification of vehicles: Policy drivers and impacts in two scenarios. In Grid Integration of Electric Vehicles in Open Electricity Markets; Wu, Q., Ed.; Wiley: West Sussex, UK, 2013; pp. 1-31. 
40. The International Council on Clean Transportation. Driving Electrification. A Global Comparison of Fiscal Incentive Policy for Electric Vehicles; The International Council on Clean Transportation: Washington, DC, USA, 2014.

41. International Energy Agency (IEA). Global EV Outlook 2016. Beyond One Million Electric Cars; OECD; IEA: Paris, France, 2016.

42. EPC. Directive 2014/94/EU of the European Parliament and of the Council of 22 October 2014 on the deployment of alternative fuels infrastructure. Official Journal of the European Union. 28 October 2014. Available online: http:/ / eur-lex.europa.eu/legal-content/EN/TXT/PDF/?uri=CELEX:32014L0094\&from= ES (accessed on 20 April 2017).

43. Malvik, H.V.; Hannisdahl, O.H.; Wensaas, G.B. The Future Is Electric! The EV Revolution in Norway-Explanations and Lessons Learned; ECEEE Summer Study Proceedings, Panel 4 Transport and Mobility: How to Deliver Energy Efficiency, 4-102-13; European Council for an Energy Efficient Economy: Stockholm, Sweden, 2013; pp. 995-1005. Available online: http:/ / proceedings.eceee.org/visabstrakt.php? event $=3 \&$ doc $=4-102-13$ (accessed on 17 May 2016).

44. Nunes, P.; Farias, T.; Brito, M.C. Enabling solar electricity with electric vehicles smart charging. Energy 2015, 87, 10-20. [CrossRef]

45. CLARS (Charging, Low Emission Zones, other Access Regulation Schemes). Overview of Low Emission Zones; CLARS; European Commission and Sadler Consultants Ltd.: Brussels, Belgium, 2015; Available online: http:/ / urbanaccessregulations.eu/overview-of-lezs (accessed on 5 March 2015).

46. Cansino, J.M.; Yñiguez, R. Promoting electro mobility in Spain. Public measures and main data (2007-2012). Transp. Res. Part D Transp. Environ. 2018, 59, 325-345. [CrossRef]

47. MOBI.E. Electric Mobility, Lisbon. 2015. Available online: http://www.mobie.pt/en/mobilidade-electrica (accessed on 2 September 2015).

48. Liaggou, C. Ministry Launches Initiative to Promote Use of Electric Cars. Ekathimerini. 3 August 2014. Available online: http://www.ekathimerini.com/4dcgi/_w_articles_wsite2_1_03/08/2014_541914 (accessed on 5 January 2016).

49. Chargeinn. New Legislation for EV Charging Infrastructure; Chargeinn: Athens, Greece, 2014; Available online: http:/ / www.chargeinn.gr/index.php/en/company-2/latest-news (accessed on 20 June 2016).

50. Government of Malta. Electromobility. Ministry for Transport and Infrastructure; Government of Malta: La Valeta, Malta, 2015. Available online: https://mti.gov.mt/en/Pages/Electromobility /Electromobility. aspx (accessed on 1 March 2015).

51. Transport Malta. Intelligent Transport Systems in Malta; Report on the Implementation of the National ITS Action Plan 2013-2017; Malta Transport Centre, Transport Malta: La Valeta, Malta, 2013. Available online: http:/ / www.transport.gov.mt/admin/uploads/media-library/files/National\%20ITS\%20Action\% 20Plan\%20for\%20Malta\%20_2013\%20-\%202017_.pdf (accessed on 1 April 2016).

52. U.S. Commercial Service. Electric Vehicles. Europe in Brief. A Reference Guide for Exporters, 2010-2011 Edition; U.S. Commercial Service-Global Automotive Team, Department of Commerce's International Trade Administration, 2010. Available online: http:/ / www.export.gov/build/groups/public/@eg_main/@byind/ @autotrans/documents/webcontent/eg_main_035287.pdf (accessed on 3 May 2017).

53. T-Trans. Electromobility Development Plan (2014-2016) in Latvia; T-Trans Project, European Commission: Brussels, Belgium, 2014; Available online: http://www.ttransnetwork.eu/ttrans/electromobilitydevelopment-plan-2014-2016-in-latvia/ (accessed on 9 January 2016).

54. Cabinet of the Ministers of Latvia. Electromobility Development Plan for 2014-2016; Cabinet of Ministers of Latvia, Latvian Transport Ministry and Road Traffic Safety Directorate: Riga, Latvia, 2014. Available online: http:/ / www.vvc.gov.lv/export/sites / default/docs/LRTA/Citi/Cab._Order_No._129_ -_On_Electromobility_Development_Plan_2014-2016.doc (accessed on 1 April 2017).

55. Ministry of Transport and Communications of the Republic of Lithuania. New Signs for Electric Vehicles Will Appear on Lithuanian Roads; Ministry of Sustainable Development and Infrastructure of the Republic of Lithuania: Vilnius, Lithuania, 2012; Available online: http:/ /sumin.lrv.lt/en/news/new-signs-for-electricvehicles-will-appear-on-lithuanian-roads (accessed on 9 January 2016). 
56. Smith, L.O.; Velten, E.K.; Donat, L.; Duwe, M.; Tallat-Kelpsaite, J. Assessment of Climate Change Policies in the Context of the European Semester. Country Report: Lithuania (Covering the period between February 2013 and November 2013); Ecologic Institute and Eclareon: Berlin, Germany, 2014; Available online: http: / / ecologic.eu/sites/files/publication/2014/countryreport_lt_ecologiceclareon_jan2014_0.pdf (accessed on 9 January 2017).

57. Eltis. Supporting the Development Electric Mobility in Prague (Czech Republic), (Updated: May 21, 2015); Eltis, The Urban Mobility Observatory, European Commission: Brussels, Belgium, 2015; Available online: http:/ / www.eltis.org/discover/case-studies/supporting-development-electric-mobility-pragueczech-republic (accessed on 3 May 2016).

58. Clean Feets. Prague to Pilot Electric Car-Sharing Scheme (Czech Republic); The Clean Fleet Project, European Commission Intelligent Energy Europe Initiative: Brussels, Belgium, 2014; Available online: http:/ /www. clean-fleets.eu/news/news-archive/october-2014/ (accessed on 3 May 2016).

59. ELMO. Estonian Electromobility Program; ELMO Program, Ministry of Economic Affairs and Communications: Brussels, Belgium, 2015; Available online: http:/ / elmo.ee/home/ (accessed on 3 March 2015).

60. TRIP. ELMO_Electric Mobility Program of Estonia. Background \& Policy Context; Transport Research \& Innovation Portal, European Commission: Brussels, Belgium, 2015; Available online: http:/ / www.transportresearch.info/web/programs/program_details.cfm?ID=45172 (accessed on 10 December 2015).

61. European Commission. Clean Power for Transport-Frequently Asked Questions. Alternative fuels: Challenges and Key Figures; Memo; European Commission: Brussels, Belgium, 2013; Available online: http:/ / europa.eu/ rapid/press-release_MEMO-13-24_en.htm (accessed on 1 April 2017).

62. Green eMotion. The Green eMotion Project_Preparing the Future of European Electromobility. Results and Findings; The Green eMotion Project; European Commission: Brussels, Belgium, 2015; Available online: http:/ /www. greenemotion-project.eu/upload/pdf/about_us/Green-eMotion_results_and_findings.pdf (accessed on 9 May 2017).

63. Electrive. Green eMotion, Hungary, Rio de Janeiro, Ankara, Tesla, Jeju (April 2, 2014); Industry Service for Electric Mobility, Electrive: Jeju, Korea, 2014; Available online: http:/ /www.electrive.com/2014/04/02/ green-emotion-hungary-rio-de-janeiro-ankara-tesla-jeju/ (accessed on 1 June 2017).

64. ESB. 1,000 Electric Vehicle Charge Points Now Installed in Ireland; ESB: Dublin, Ireland, 2012; Available online: https:/ / www.esb.ie/main/press/pressreleaseWS.jsp?id=2334 (accessed on 6 June 2016).

65. ESB. ESB Completes Pilot Electric Vehicle Project for the European Commission; ESB: Dublin, Ireland, 2014; Available online: https: / / www.esb.ie/main/press/pressreleaseWS.jsp?id=4214 (accessed on 9 May 2017).

66. Ministry of Sustainable Development and Infrastructure of Luxembourg. Sixth National Communication of Luxembourg under the United Nations Framework Convention on Climate Change Including Luxembourg's Biennial Report No 1; Ministry of Sustainable Development and Infrastructure-Department of the Environment: Luxembourg, 2014; Available online: http://unfccc.int/files/national_reports/annex_i_natcom/submitted_ natcom/application/pdf/dev_nc6_final.pdf (accessed on 1 June 2017).

67. International Energy Agency (IEA). Energy Policies of IEA Countries-Luxembourg. 2014 Review; OECD; IEA: Paris, France, 2014; Available online: http:/ / www.iea.org/publications/freepublications/publication/ Luxembourg2014.pdf (accessed on 1 April 2017).

68. Donat, L.; Velten, E.K.; Najdawi, C. Assessment of Climate Change Policies in the Context of the European Semester. Country Report: Luxembourg (Covering the Period between February 2013 and November 2013); Ecologic Institute and Eclareon: Berlin, Germany, 2014; Available online: http:/ / ecologic.eu/sites / files/publication/2014/ countryreport_lu_ecologiceclareon_jan2014_0.pdf (accessed on 6 June 2017).

69. Van der Beesen, P.; Fruianu, M.; Reitsma, S.; Williams-Jacobse, J. (Eds.) E-Mobility in The Netherlands. We Are Holland (a Pilot Area) Ready to Market e-Mobility; NL Agengy, Ministry of Economic Affairs: Utrecht/The Hague, The Netherlands, 2013; Available online: http://www.rvo.nl/sites/default/files/2013/11/Emobility\%20in\%20the\%20Netherlands.pdf (accessed on 9 January 2016).

70. Kampman, B.; Braat, W.; van Essen, H.; Gopalakrishnan, D. Impacts of Electric Vehicles—Deliverable 4. Economic Analysis and Business Models; CE Delft (Committed to the Environment, Delft): Delft, The Netherlands, 2011; Available online: http:/ / ec.europa.eu/clima/policies/transport/vehicles /docs/d4_en.pdf (accessed on 6 June 2017). 
71. Christiaens, J. Incentives for Hybrid Car Owners in Poland (Poland) (Updated: 1 August 2014); Eltis (the Urban Mobility Observatory), European Commission: Brussels, Belgium, 2014; Available online: http:/ /www.eltis. org/discover/news/incentives-hybrid-car-owners-poland-poland-0 (accessed on 6 May 2016).

72. E3M-Lab. Assessment of the Implementation of a European Alternative Fuel Strategy and Possible Supportive Proposals; Final Report to the European Commission in the Framework of Contract TREN/R1/350-2008 LOT3-MOVE C1/497-1-2011; E3M-Lab, Institute of Communication and Computer Systems, and National Technical University of Athens: Athens, Greece, 2012; Available online: http:/ / ec.europa.eu/transport/ themes/urban/studies/doc/2012-06-cts-implementation-study.pdf (accessed on 6 May 2016).

73. European Parliament. European Parliament Resolution of 6 May 2010 on Electric Cars. Official Journal of the European Union. 15 March 2011. Available online: http:/ / eur-lex.europa.eu/legal-content/EN/TXT/PDF/ ?uri=OJ:C:2011:081E:FULL\&from=EN (accessed on 6 May 2017).

74. Krause, R.M.; Carley, S.R.; Lane, B.W.; Graham, J.D. Perception and reality: Public knowledge of plug-in electric vehicles in 21 U.S. cities. Energy Policy 2013, 63, 433-440. [CrossRef]

75. Smith, L.O.; Velten, E.K.; Prahl, A.; Duwe, M.; Pilvik, R. Assessment of Climate Change Policies in the Context of the European Semester. Country Report: Estonia (Covering the Period between February 2013 and November 2013); Ecologic Institute and Eclareon: Berlin, Germany, 2014; Available online: http:/ / ecologic.eu/sites / files / publication/2014/countryreport_ee_ecologiceclareon_jan2014_0.pdf (accessed on 1 April 2016).

76. Trip, J.J.; Lima, J.; Bakker, S. Electric Mobility Policies in the North Sea Region Countries; Activity 3.3 of the Interreg IVB Project E-Mobility NSR; Electric Mobility Network, North Sea Region, Delft University of Technology, and The European Regional Development Fund: Delft, The Netherlands, 2012; Available online: http:/ / e-mobility-nsr.eu/fileadmin/user_upload/downloads/info-pool/3.3_-_E-mobility_policies_ in_the_NSR_countries.pdf (accessed on 1 April 2016).

77. Pablo-Romero, M.P.; Sánchez-Braza, A.; González-Limón, J.M. Covenant of Mayors: Reasons for being an environmentally and energy friendly municipality. Rev. Policy Res. 2015, 32, 576-599. [CrossRef]

78. Sánchez-Braza, A.; Cansino, J.M.; Lerma, E. Main drivers for local tax incentives to promote electric vehicles: The Spanish case. Transp. Policy 2014, 36, 1-9. [CrossRef]

79. Wang, R. Leaders, followers, and laggards: Adoption of the US Conference of Mayors Climate Protection Agreement in California. Environ. Plan. C 2012, 30, 1116-1128. [CrossRef]

80. ACEA Tax Guide: EU Highlights; European Automobile Manufacturers Association: Brussels, Belgium, 2015.

81. ACEA Tax Guide 2015; European Automobile Manufacturers Association: Brussels, Belgium, 2015. 